\title{
Coexistence of urban uses and shellfish production in an upwelling-driven, highly productive marine environment: the case of the Ría de Vigo (Galicia, Spain)
}

\author{
Emilio Fernández ${ }^{1}$, Xosé Anton Álvarez-Salgado², Ricardo Beiras ${ }^{1}$, Aida \\ Ovejero $^{1}$, Gonzalo Méndez ${ }^{1}$
}

${ }^{1}$ Faculty of Marine Science. Universidade de Vigo. Campus of International Excellence Campus do Mar.

2 Institute of Marine Research. CSIC. Vigo.

\begin{abstract}
The Ría de Vigo, located at the northern border of the Iberia-NW Africa eastern boundary upwelling ecosystem, is an incised deep (45 m maxim depth) valley originated by the combined action of tectonic and erosive processes. Upwelling events promote a quick renewal (3-4 days) of the volume of water in the Ría, which is replaced by cold, oxygenated and nutrient-rich subsurface oceanic water, giving rise to nutrient fertilization of the embayment that translates into high primary production rates (ca. $3 \mathrm{~g}$ $\mathrm{C} \mathrm{m} \mathrm{m}^{-2} \mathrm{~d}^{-1}$ ). This high productivity allows the development of an important shellfish exploitation activity. The Ría de Vigo has 529 rafts where 37000 tons of mussels are produced annually. This territory has been subjected to an increasing human pressure since the early XX century deriving in an intense landscape transformation. The city of Vigo showed a six-fold increase in the number of inhabitants from 1900 to 2001 and more than $21 \%$ of the land in the study area is currently artificial. Therefore, urban and industrial activities coexist with local fisheries and shellfish mariculture that accounts for ca. $7 \%$ of the income and employment in this urban region. Incomplete depuration of wastewater in treatment plants explain the relatively high contribution $(22 \%)$ of sewage-derived nutrients to the total allochtonous fertilization in the Ría. Furthermore, and given the importance of shellfish production, microbial pollution originated from urban wastewater is considered as the main environmental threat of the Ría de Vigo. The dependence of the local economy on marine renewable resources together with the limitation of the natural productivity of the Rías imposed by anthropogenic pressure lies behind a significant fraction of the conflicts occurring in the region during the past two decades. The characteristics of Ría de Vigo, described in this review, confer this coastal ecosystem unique conditions as a natural laboratory where the interaction between human activity and marine ecological processes can be studied within the framework of the World Harbour Project.
\end{abstract}

\section{Introduction}

The Ría de Vigo, located in the Northwest Iberian Peninsula (Spain), is one of the European harbours included in the World Harbour Project (WHP). The Ria de Vigo is not a heavily populated area, has not a large comercial port and is not an intensively 
polluted area nor a pristine environment when contrasted with the rest of WHP harbours. However, it is a perfect example of the coexistence of human populations, the economic activity associated to them, the consequent alteration of the marine ecosystem, including degradation of water quality conditions, the production of a considerable amount of shellfish and the presence of well preserved marine ecosystems, in a very reduced coastal area $\left(156 \mathrm{~km}^{2}\right)$ affected by wind-driven upwelling, therefore highly dependent on processes occurring at the global scale. In this regard, it is a suitable model system to explore the interaction among production ecosystem functions and anthropogenic environmental changes at different scales.

The coexistence of fishing and aquaculture activities in relatively polluted areas is a widespread phenomenon that has been intensively studied given its relevance for management and regulation purposes. Thus, for example, descriptions of mixed inputs of pollutants into St. Lawrence estuary (Pellerin and Amiard, 2009), dicharges from mine activities in Greenland fjords (Søndergaard et al., 2011), anthropogenic inputs from industrial origin and urban effluents in the Bay of Muggia (North Adriatic Sea) (Moschino et al., 2016) or heavy metals pollution from anthropogenic activities in the southern coast of China (Zhang et al., 2012), in relation to the production of marine resources have been reported in the literature.

Human settlements and economic activities associated to the coastline of the Ría de Vigo date from before the Roman colonization period. However, the position of the city of Vigo as the most populated in the region and its role as an important regional communication node is quite recent, late XIX century, associated to the development of port infrastructures. The industrial revolution and ship motorization in the XIX century, brought about the need and the viability to build larger vessels which required greater depths in the ports, natural conditions already provided by the port of Vigo, where dredging was not and still is not necessary. In the second half of the XX century, the Port of Vigo became the main port of shipment of the Galician transoceanic migration, with ca. 1.2 million Galician people (ca. $40 \%$ of the current population of the region) migrating to South América from 1911 to 1970 (Campillo et al., 1993). A sustained population growth was observed in the coastal municipalities of the Ría, particularly in Vigo, where a six-fold increase in the number of inhabitants occurred from 1900 to 2001. The urbanization of Vigo spread all along the coastal margin, as a consequence of the port activity, and also to the interior valleys were natural and agricultural land was transformed for the development of new industrial developments, largely related to the automotive industry. Currently, 300000 inhabitants live in the City of Vigo and 428000 in the eight municipalities surrounding the Ría. 
The key geographical feature and identity element for the human populations inhabiting the area is, undoubtedly, the Ría. "Rías" are penetrations of seawater into the coast due the submersion of river watersheds that extend along the coastline. Von Richthofen (1886) was the first author who proposed the use of the term "Ría" to define a particular coastal typology characterized by the existence of a valley occupied by seawater, taking as an example the Galician Rías, their formation being related to tectonic and eustatic processes as well as regional and local singularities (Méndez \& Vilas, 2005). They are incised valleys where only the inner brackish water zone can be considered an estuary (Evans and Prego, 2003), being therefore divided into an inner zone close to the river mouth with typical estuarine characteristics and an outer, deeper zone, usually separated from the on-shelf ocean by an archipelago of small islands which constitute the natural area Atlantic Island National Park.

The Galician Rías in general, and the Ría de Vigo in particular, are highly productive ecosystems that allow the development of significant traditional fish and shellfish exploitation activities as well as an intense mussel raft aquaculture. This high capacity to produce biomass is related to their geographical location at the northern border of the Iberia-NW Africa eastern boundary upwelling ecosystem (Barton, 1998; Arístegui et al. 2009; Álvarez-Salgado et al. 2010). During upwelling events, subsurface (150-200 m) water upwells over the continental shelf entering the bottom layer of the Ría de Vigo, promoting a quick renewal of the water in the embayment (Álvarez-Salgado et al. 2000, Barton et al. 2015). The resultant inflow of shelf bottom water into the ría give rise to nutrient fertilization of the embayment triggering the production of high amounts of phytoplankton biomass.

The Ría de Vigo is impacted by diverse anthropogenic activities reflected, for instance, by increases in sedimentation rates over the last centuries (Pérez-Arlucea et al., 2005; Álvarez-Iglesias et al., 2007; Bruschi et al., 2013) or by increasing levels of some heavy metals, such as lead and copper, in the sediments (Prego and Cobelo, 2003; Howarth et al., 2005; Evans et al., 2011). However, the input of incompletely untreated urban sewage waters into the water column is likely to be the most important environmental problem faced by the socio-ecosystem of the Ría de Vigo given its potential ability to affect one of the most significant ecological services provided by the Ria, the annual production of 37000 tons of mussels (Suris-Regueiro, 2014).

In this paper, a review of the main environmental, economic and social characteristics of the Ría de Vigo is presented with the aim of illustrating the potential of this harbour to contribute to the main goals of the World Harbour Project. For this purpose, we used existing knowledge accumulated in the scientific literature and also retrieved and processed available information to investigate temporal trends and magnitudes of land use changes and marine land reclamation and explored the relative contribution of 
different types of conflicts in the study area. We aimed at presenting the relationship among the hydrodynamics of the Ría de Vigo, controlled by coastal upwelling, shellfish production and human-derived environmental impacts.

\section{Methods and study area}

\section{Study area}

The Ría de Vigo, located at the southern region of Galicia (Northwest Iberian Peninsula; Spain) is $32.8 \mathrm{~km}$ long, gradually widening from $0.6 \mathrm{~km}$ at the inner zone to $15.5 \mathrm{~km}$ at its mouth, covering a total surface of $156 \mathrm{~km}^{2}$ with a volume of water of ca. $3000 \mathrm{~km}^{3}$. Its maximum depth is $45 \mathrm{~m}$ at the southern channel (Fig. 1).
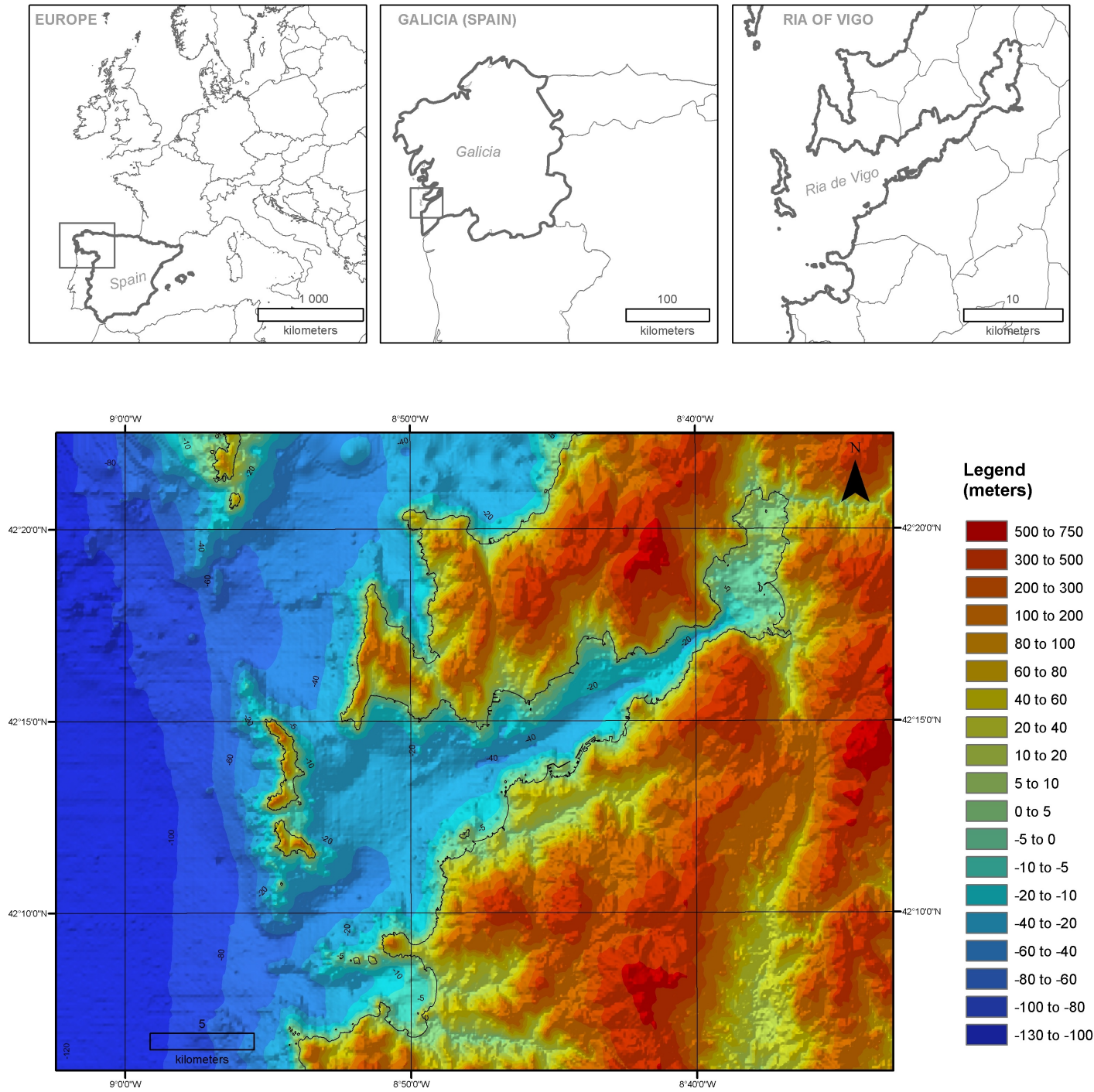

Figure 1. Geographical location of the Ría de Vigo (Northwest Iberian Peninsula; Spain), showing its bathymetry and topography. 
The spatial distribution of surface sediment typology in the Ría de Vigo is related to bathymetry, to subsurface currents associated to rivers and to the hydrodynamics of water bodies, mainly waves and tidal currents (Vilas et al., 2005). The inner part of the Ría de Vigo is characterized by the presence of fine sediments (lime) whereas a relatively higher contribution of the sand fraction is found associated to intense wave activity in the outer part the Ría.

\section{Methods}

Geographic Information System (GIS) tools were used in this study to analyse the magnitude of land reclamation and changes in land uses. All the available geographic information was harmonized and combined prior to geographical analyses.

In order to display and quantify changes due to anthropization and alteration of the coastline, the evolution of the shoreline was digitized using ArcView GIS software. Three different shorelines were derived, corresponding to the years 1850, 1912 and 2008, using aerial photography and antique cartography (maps and nautical charts). This information was integrated into a GIS overlapping it with the base cartography (Mapa Topográfico Nacional, scale 1:25000 - official cartography) and with the orthophotographs of the PNOA (Plan Nacional de Ortofotografia Aérea), allowing us to quantify total lengths, the natural and antrophized percentages of the coastline and the occupied marine surface.

Artificialization and other changes in land uses in the study area were analized by comparison of the delimited polygons obtained from the Corine Land Cover Programme corresponding to 1990 and 2006. We reclassified the existent classes into the 6 groups defined in Figure 2, to simplify the diversity of uses.

Conflicts related to environmental pressures were identified by undertaking a thorough review of the local newspapers from 2005 to 2015. All the news were associated to 11 typologies of conflicts that were previoulsly defined and then geographically located. 


\section{Results and discussion}

\section{Human pressure: economic activity and land use dynamics}

The gross domestic product of the study area was 9500 million dollars in 2012, corresponding $82.5 \%$ of this value to Vigo. The traditional agriculture and fishing activities are now enriched by new industrial sectors, many of them related to the maritime industry (fishing, shipyards, port activities, etc.). The canning industry is a significant component of the economy of the Ría. In the last decades, the fish transformation and freezing industry grew intensively. Vigo is one of the largest fishing ports worldwide. Total fish landings for human consumption were about 865000 tons in $2014,81 \%$ of them being frozen fish. A key milestone for the industrial development of the region was the implantation of the automotive industry in Vigo in 1958, which currently represents $23.3 \%$ of the total exportation of the region and $32 \%$ of the total trade of the port of Vigo (4087398 tons; 13100 million dollars in 2014) (Autoridad Portuaria de Vigo, 2015).

The natural value of the territory, mainly associated to the marine domain (sandy beaches, nautical sports, etc.), is the main attractive of the region for tourism. This activity accounts for a significant component of the economy of the region, ca. $10 \%$ of the regional GDP, but is also a source of conflicts with other traditional uses and with the conservation of natural areas.

The urbanization process largely associated to the demographic and industrial development of the city of Vigo, derived in sharp land use changes in the territory surrounding the Ría. In this study, an analysis was carried out using the results from the Corine land Cover Project which allowed to quantitatively evaluate the intensity of transformation and the dynamics of land use classes for the period 1990-2006, when population growth in the region already had slowed down. Artificial land increased by 8 $\mathrm{km}^{2}$ in this period, mainly due to new industrial developments and urbanizations. This value corresponded to $2.1 \%$ of the total area of the municipalities $\left(380 \mathrm{~km}^{2}\right)$. More than half of the new artificial land was previously agricultural land and $4.03 \mathrm{~km}^{2}$ were transformed in Vigo.

The result of more than a century of intense landscape transformation can be visualized in Figure 2. More than $21 \%$ of the territory in the study area is currently artificial. This anthropogenically transformed land is mainly located close to the coastline and in the southern margin of the Ría, where the signature of the city of Vigo is apparent. The littoral area is occupied by high and medium-density urbanizations and maritime industrial and commercial activities but also by some well preserved areas with high environmental values and of interest for tourism. The areas more distant from the 
coastline are generally characterized by sprawled isolated urbanizations and forests. The need for the extension of the port and other industries gave rise to additional increases in artificial land in the interior of the municipalities.

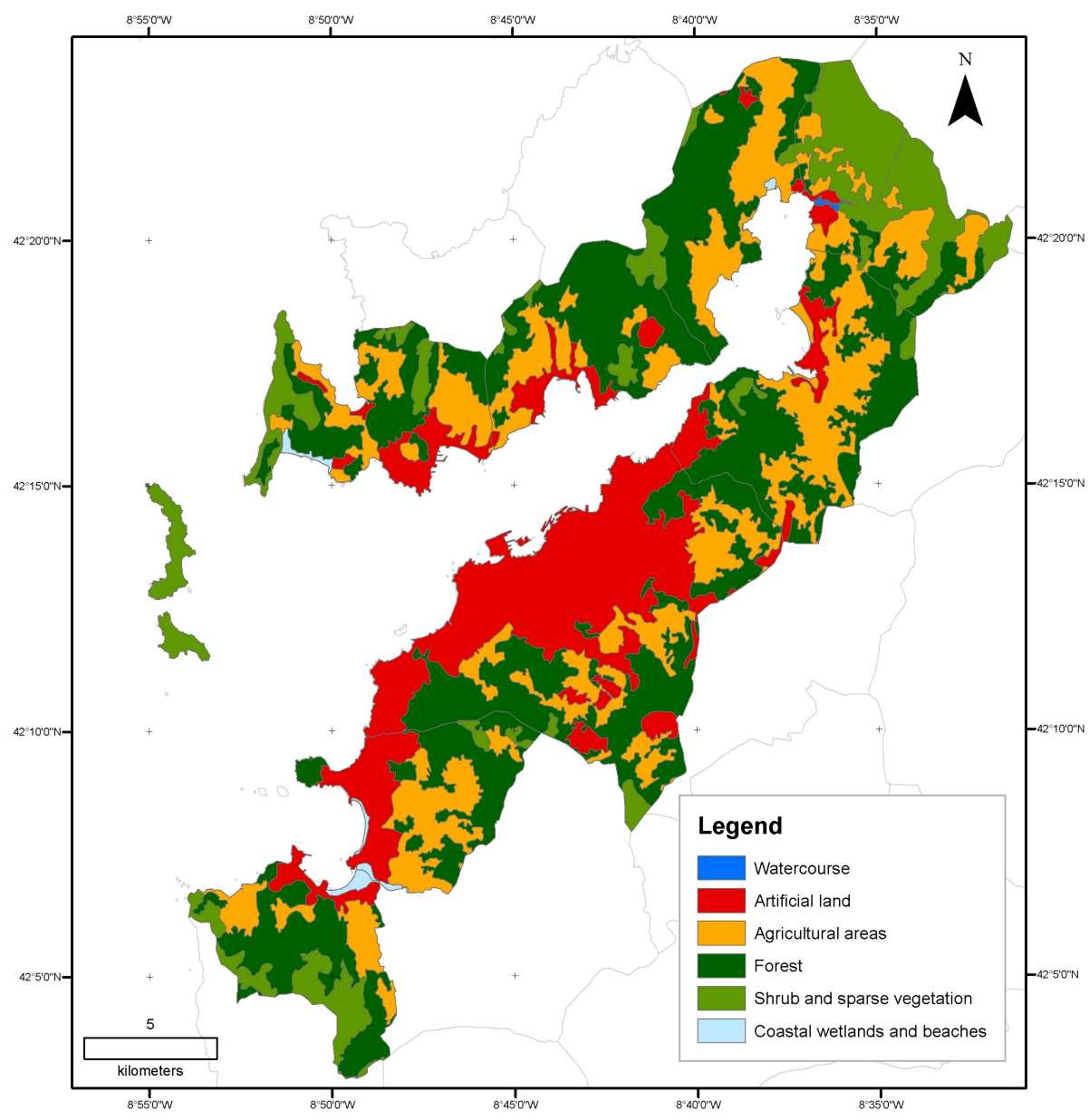

Figure 2.- Land uses in the municipalities surrounding the Ría de Vigo in 2006 derived from Corine Land Cover data.

An intense land reclamation process occurring during the last century associated to the development of the city and the port of Vigo derived from the analysis of the evolution of the coastline since 1850 undertaken in this study. The $137.5 \mathrm{~km}$ of natural coastline estimated for the Ría de Vigo in 1850 (scale 1:25000), decreased to the $89.5 \mathrm{~km}$ estimated for 2008. Not only artificial structures substituted the natural coastline, but land reclamation occupied $3.9 \mathrm{~km}^{2}$, generating $86.8 \mathrm{~km}$ of new, artificial coastline. The total length of the coastline in the Ría de Vigo is $191.5 \mathrm{~km}$, showing a $39 \%$ increase in the last 150 years (Figure 3 ). 

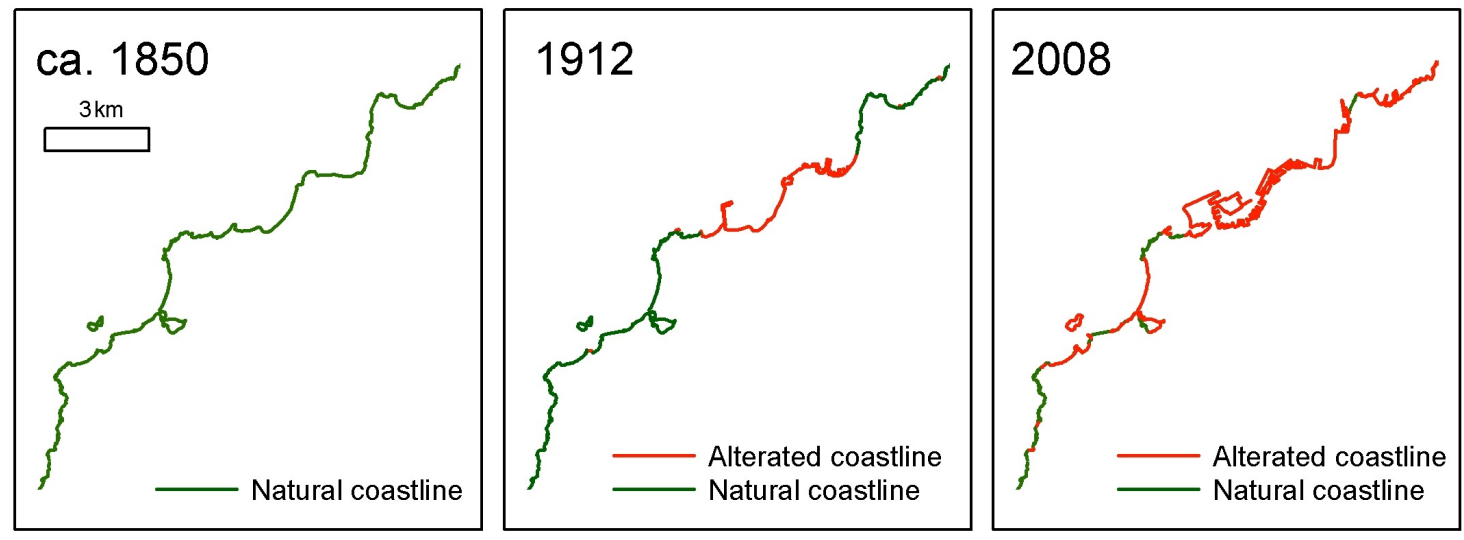

Figure 3. Temporal evolution of the transformation of the coastline in the municipality of Vigo.

In spite of the intense human settlement in the littoral of the Ría de Vigo, and the consequent environmental degradation, as reflected by the increasing rate of land transformation, particularly in the middle zone of the embayment (Figure 2), a number of natural areas remained in a relatively satisfactory state of conservation (Figure 4). The European Union network of nature protection areas, Natura 2000, is also represented in the Ría. Although the aim of the network is to assure the long-term survival of threatened species and habitats, conservation policies in these spaces aspire to be compatible with sustainable human activities.

Uses of the marine domain in the Ría de Vigo are multiple and frequently overlap over the same water parcels (Figure 4). Maritime routes, anchorage areas, fishing grounds, shellfish beds and mussel rafts are the main activities occurring in this area. Nevertheless, they coexist with other less representative uses such as leading lines, submarine cables and submarine sewage outfalls. Areas demarcated for the development of mariculture activities occupy a considerable extension of the Ría, with shellfish beds and mussel rafts extending over $24.6 \mathrm{~km}^{2}$ and $8.5 \mathrm{~km}^{2}$, respectively. The Ría de Vigo has 529 rafts where 37000 tons of mussels are produced annually (Suris-Regueiro, 2014). Vigo is, therefore, a coastal city where industrial and urban activities coexist with the presence of local fisheries and shellfish mariculture representing a significant share of the regional economy. Based on an input-output approach, Surís-Regueiro et al. (2014) concluded that mariculture and extractive fishing is a relevant economic activity in the Ría de Vigo area, accounting for ca. $7 \%$ of the income and employment in this urban region. The high production of fish and shellfish in the Ría is supported by the high primary production rates characteristic of this wind-driven upwelling system. 


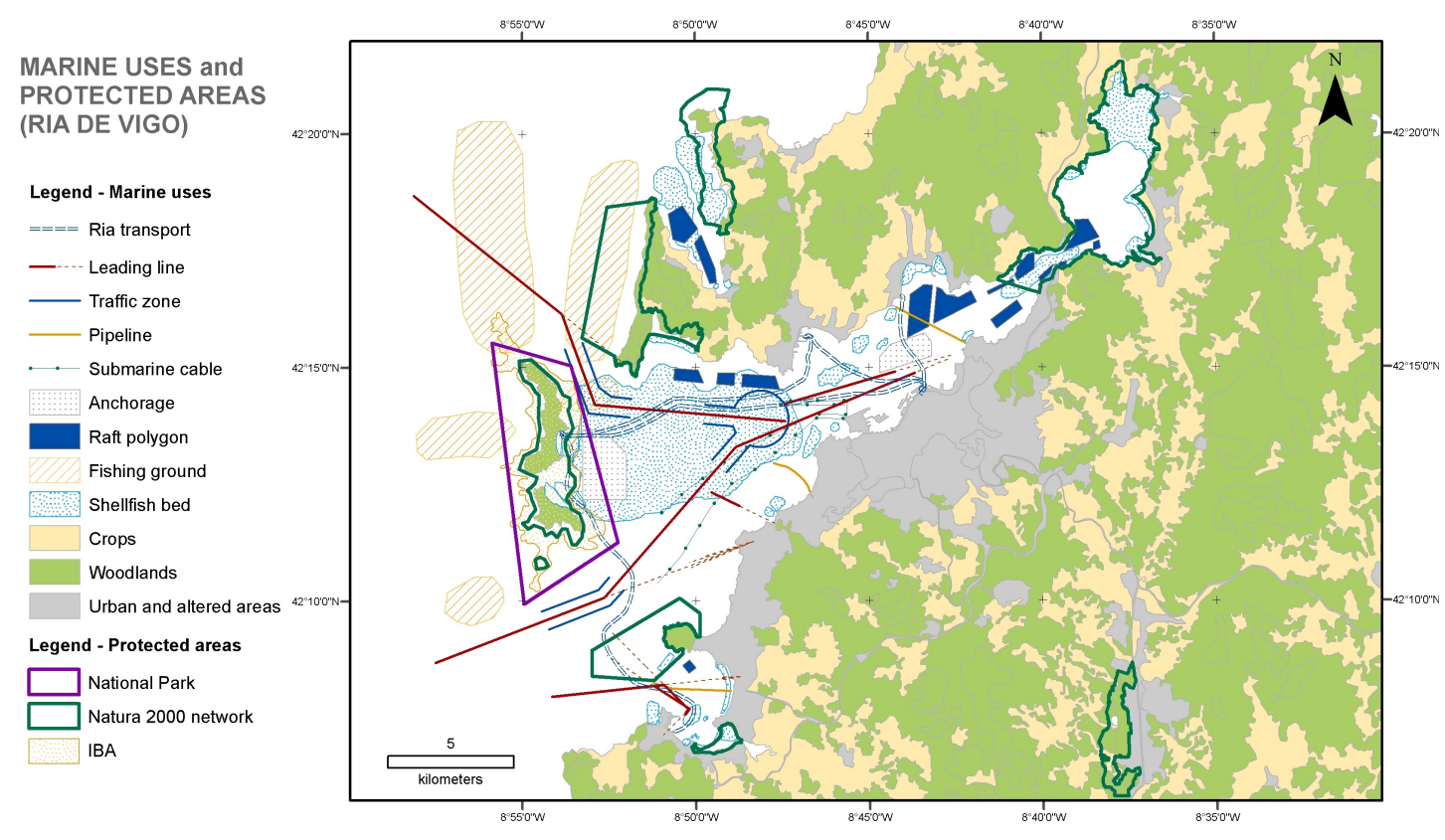

Figure 4.- Marine uses in the Ría de Vigo in 2014 and environmentally protected areas in the Ría de Vigo. (IBAs: Important Bird and Biodiversity Areas)

The biophysical framework: a highly productive wind-driven coastal upwelling system

At the latitude of the Ría de Vigo $\left(42.2^{\circ} \mathrm{N}\right)$, coastal upwelling is seasonal, from April to September, when northerly winds blow intermittently. As a result, the average offshore Eckman transport over the upwelling season, a measure of the volume of water upwelled per kilometre of coast, is moderate, ca. $250 \mathrm{~m}^{3} \mathrm{~s}^{-1} \mathrm{~km}^{-1}$, compared with the intensity of upwelling off NW Africa, ca. $1000 \mathrm{~m}^{3} \mathrm{~s}^{-1} \mathrm{~km}^{-1}$ (Arístegui et al. 2009). Despite the intermittency and moderate intensity of coastal winds, these upwelling events over the shelf have a foremost influence on the hydrography and circulation of the Ría de Vigo. The bathymetry of the embayment and the freshwater discharge contribute to modulate the influence of the external forcing (Barton et al. 2015). Continental runoff to the Ría de Vigo is also seasonal, being lower during the upwelling season (average, ca. $15 \mathrm{~m}^{3} \mathrm{~s}^{-1}$; Nogueira et al. 1997). Intense upwelling events promote that water in the Ría de Vigo is flushed out in 3-4 days, being replaced by cold, oxygenated and nutrient-rich ENACW (Álvarez-Salgado et al. 2000, Barton et al. 2015).

Considering the average offshore Eckman transport over the upwelling season of 250 $\mathrm{m}^{3} \mathrm{~s}^{-1} \mathrm{~km}^{-1}$, and the inorganic nitrogen concentration of the upwelled water, around 6 $\mu \mathrm{M}$ (Álvarez-Salgado et al. 2002), the resultant inflow of shelf bottom water into the 
Ría would be about $2500 \mathrm{~m}^{3} \mathrm{~s}^{-1}$ (Alvarez-Salgado et al. 2000), giving rise to fertilization of the embayment with $15 \mathrm{~mol} \mathrm{~s}^{-1}$ of inorganic nitrogen (Fig. 5). The average inorganic nitrogen concentration in bottom waters of the middle zone of the Ría de Vigo is $9.4 \mu \mathrm{M}$ (Nogueira et al. 1997). This nitrogen enrichment, mainly in the form of ammonium $(2.6 \mu \mathrm{M})$, is due to remineralization in the surface sediments of the Ría during the wind relaxation periods between upwelling events. The inorganic nitrogen flux from the sediments to the water column is ca. $6 \mathrm{~mol} \mathrm{~s}^{-1}, 83 \%$ as ammonium (Alonso-Pérez and Castro, 2014). The continental freshwater discharge from rivers, with an average flow of $15 \mathrm{~m}^{3} \mathrm{~s}^{-1}$ and an inorganic nitrogen concentration of $17 \mu \mathrm{M}$ (Gago et al. 2005), adds only $0.25 \mathrm{~mol} \mathrm{~s}^{-1}$ to the fertilization of the Ría de Vigo. Rainwater also represents a minor contribution to the fertilization of the embayment of $0.20 \mathrm{~mol} \mathrm{~s}^{-1}$, resulting from an average precipitation over the upwelling season of 500 $\mathrm{mm}$ and an average inorganic nitrogen concentration of $40 \mu \mathrm{M}$ (unpub. data). Inorganic nitrogen in freshwater is mainly in the form of nitrate $(15 \mu \mathrm{M})$, although ammonium is also significant $(2 \mu \mathrm{M})$. Conversely, in rainwater, nitrate and ammonium concentrations are both around $20 \mu \mathrm{M}$. Finally, the effluents from the twelve waste water treatment plants (WTP) operating in the Ría de Vigo, with a total flow of $3.23 \mathrm{~m}^{3} \mathrm{~s}^{-1}$, deliver 4.3 mol s${ }^{-1}$ of nitrogen, $68 \%$ in the form of ammonium (CSIL; 2012). Most of the discharge (86\%) occurs in the WTP of the city of Vigo, located in the outer zone of the Ría. Evidences of anthropogenic nitrogen inputs from wastewater have been detected from $\mathrm{N}$ isotopic signatures of both sediments (unpub. data) and macroalgae (Viana and Bode 2013). Therefore, considering only allochthonous sources, fertilization of the Ría de Vigo occurs essentially by coastal upwelling ( $76 \%$ of the nutrient input), but the contribution of wastewater is also substantial ( $22 \%$ of the nutrient input), whereas fresh and rain water inputs are residual (2\%). If the surface sediments of the Ría de Vigo are considered as an external source, then coastal upwelling represents 58\%, surface sediments $23 \%$, sewage $17 \%$ and continental and atmospheric sources $2 \%$ of the inorganic nitrogen input. 


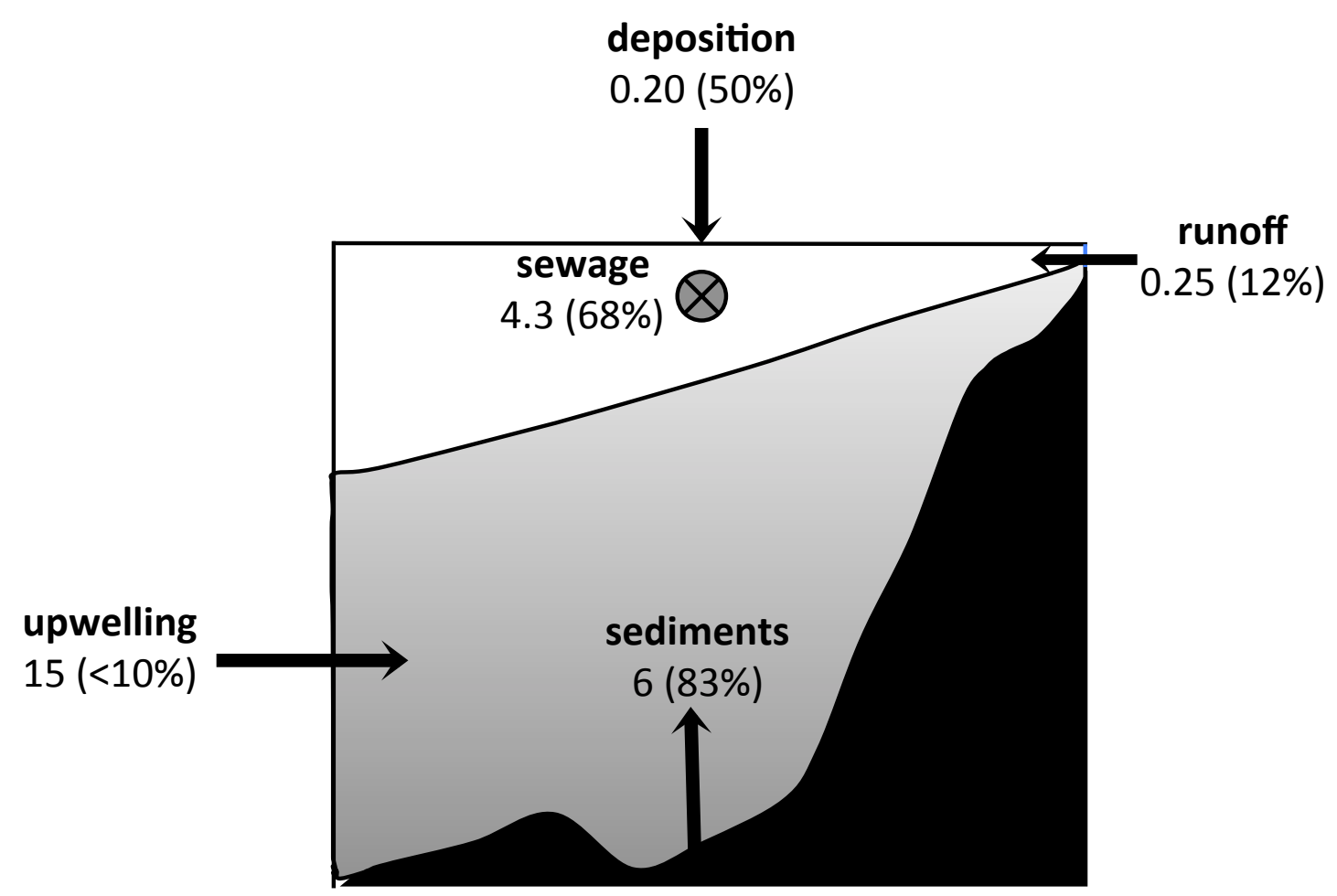

Figure 5. Average fluxes of inorganic nitrogen into the Ría de Vigo during the upwelling season (in mol $\mathrm{N} \mathrm{s}^{-1}$ ). The numbers in brackets are the percentage of inorganic nitrogen in the form of ammonium.

During the wind relaxation periods following upwelling events, nutrients introduced by upwelling are efficiently used within the embayment (Álvarez-Salgado et al. 2010), giving rise to the high primary production rates (ca. $3 \mathrm{~g} \mathrm{C} \mathrm{m}^{-2} \mathrm{~d}^{-1}$ ) measured in the central zone of the Ría de Vigo during the upwelling season (Fig. 6). About 25\% of the photosynthetically produced organic matter is respired in the photic layer, $43 \%$ sinks to the aphotic layer and the remaining $32 \%$ is available to be exported to the outer Ría or the shelf in the form of suspended and dissolved organic carbon or to be transferred to higher trophic levels, including artisanal fisheries and extensive mussel aquaculture (Figueiras et al. 2002). It has been estimated that $17 \%$ of the $1.3 \mathrm{~g} \mathrm{C} \mathrm{m}^{-2} \mathrm{~d}^{-1}$ that sinks to the aphotic layer is respired in the water column and $23 \%$ in the surface sediments (Alonso-Pérez et al. 2015), whereas the remaining 60\% could be transported to the inner Ría or transferred to higher trophic levels. It should be noted that respiration rates in the sediments below the mussel rafts are an order of magnitude higher, ca. $2 \mathrm{~g} \mathrm{C} \mathrm{m}^{-2} \mathrm{~d}^{-1}$ (Alonso-Pérez et al. 2010), but the intermittency of upwelling events prevent the development of hypoxic conditions in bottom waters and washes out of the Ría most of the dissolved or suspended pollutants (Barton et al. 2015). 


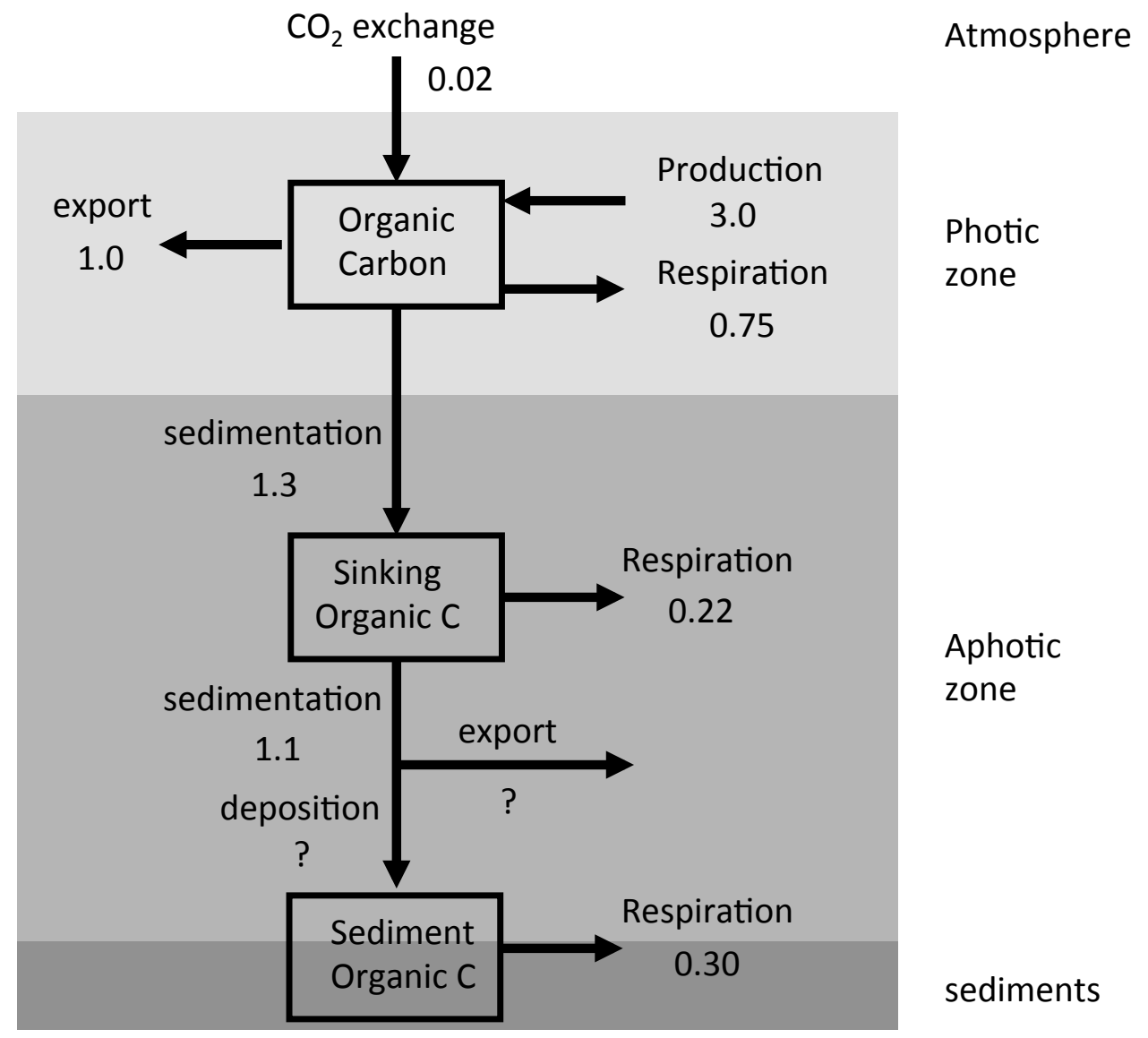

Figure 6. Carbon budget of the central zone of the Ría de Vigo during the upwelling season (in $\mathrm{g} \mathrm{C} \mathrm{m}^{-2} \mathrm{~d}^{-1}$ ). Adapted from Arístegui et al. (2009) after adding the respiration rates in the aphotic layer and the sediments from Alonso-Pérez et al. (2015).

The primary production required to support fish and shellfish extraction in the Ría de Vigo was estimated as $168 \mathrm{~g} \mathrm{C} \mathrm{m}^{-2} \mathrm{y}^{-1}$ (or $0.5 \mathrm{~g} \mathrm{C} \mathrm{m}^{-2} \mathrm{~d}^{-1}$ ) (Alonso-Pérez et al. 2015), which represents about $30 \%$ of the organic material not respired in the water column or the sediments during the upwelling season $\left(1.7 \mathrm{~g} \mathrm{C} \mathrm{m}^{-2} \mathrm{~d}^{-1}\right)$. On an annual basis, the estimated primary production of the Ría de Vigo is ca. $1.8 \mathrm{~g} \mathrm{C} \mathrm{m}^{-2} \mathrm{~d}^{-1}$ (or $650 \mathrm{~g} \mathrm{C} \mathrm{m}^{-2}$ $\mathrm{y}^{-1}$ ) and the pelagic and benthic respiration sums up ca. $0.9 \mathrm{~g} \mathrm{C} \mathrm{m}^{-2} \mathrm{~d}^{-1}$ (or $333 \mathrm{~g} \mathrm{C} \mathrm{m}^{-2}$ $\mathrm{d}^{-1}$ ); therefore, $53 \%$ of the material not respired in the water column or the sediments (317 $\left.\mathrm{g} \mathrm{C} \mathrm{m}^{-2} \mathrm{~d}^{-1}\right)$ is required to support extractive activities in the Ría de Vigo (AlonsoPérez et al. 2015). 


\section{Threats for shellfish aquaculture}

Molluscan shellfish are a valuable source of protein and a highly appreciated and commercially important food in many coastal cultures world-wide. As active filter feeders, they process hundreds of litres of water per day, and concentrate from water all kinds of contaminants within their edible tissues: chemicals, biotoxins, parasites and infectious bacteria and viruses (Richards 2003). As a result, a wealth of regulations and controls involved in the harvesting and commercialization of mollusks and other seafood were approved to avoid hazards to human health. Current regulations include controls on the levels of marine biotoxins, chemical contaminants, and infectious microorganisms.

The occurrence of toxic phytoplankton blooms in the Ría de Vigo appear to be closely controlled by the hydrodynamics of the upwelling-downwelling process. During upwelling events, phytoplankton is dominated by chain-forming diatoms of medium and large size, including Pseudo-nitzschia spp. (Figueiras et al. 2002, González-Vilas et al. 2014). Some members of this diatom genus cause Amnesic Shellfish Poisoning (ASP) outbreaks. During the transition from upwelling to downwelling favorable seasons, toxic blooms of the DSP-forming species Dinophysis acuta (Reguera et al. 1995) and the Paralytic Shellfish Poisoning (PSP) chain-forming species Gymnodinium catenatum (Fraga et al. 1988, Figueiras et al. 1994) occurs. Weakening of coastal upwelling reported at our latitudes over the last 50 years (Álvarez-Salgado et al. 2008, Pérez et al. 2010, Gómez-Gesteira et al. 2011b), results in an increase of both the renewal time of the Ría and the number of days that the mussel farms are closed to extraction (Alvarez-Salgado et al. 2008, Pérez et al. 2010).

Accumulation of $\mathrm{Pb}, \mathrm{Cu}$ and $\mathrm{PCBs}$ by shellfish from the Ría the Vigo has been reported in the literature. $\mathrm{Pb}$ accumulation in the bivalve Dosinia exoleta is currently a serious economic and ecological problem in the Galician Rías, since large individuals may exceed the $\mathrm{Pb}$ limit for commercialization of 1.5 ppm (Sánchez-Marín \& Beiras 2008). Historical chronic $\mathrm{Pb}$ pollution in the inner part of the Ría de Vigo is also well known, although the situation is slowly improving, after phasing out point-source emissions (Gómez-Gesteira et al. 2011a). In contrast, $\mathrm{Cu}$ is the trace metal currently posing the highest risk to shellfish production, due to the narrow margin between the environmental concentrations measured in the water of the Ría ( 0.3 to $3 \mathrm{ppb}$, Durán \& Nieto 2011) and the toxicity threshold for the extremely sensitive early life stages of bivalves and echinoderms, ca. $10 \mathrm{ppb}$. Concentrations of polychlorinated biphenyls, PCBs, are noticeably high near the harbour area, as indicated by bioaccumulation in 
wild mussels (10-100 ng.g ${ }^{-1}$ wet weight), but generally $<5$ ng. $\mathrm{g}^{-1}$ otherwise (Beiras et al. 2003, Carro et al. 2010).

The high number of viruses, bacteria and parasites potentially transmitted from human wastes in sewage makes impractical the individual control of each species. Thus, the most abundant enteric bacteria, Escherichia coli, is universally used as indicator of faecal contamination and thus of the potential presence of enteric organisms capable of causing disease. Bivalve production areas are classified following Regulation EC $854 / 2004$ in one of three categories according to the level of faecal contamination. Class A are areas from which live bivalve mollusks may be collected for direct human consumption because they meet the microbiological criteria established in Regulation EC 2073/2005. Mollusks from Class B or C areas cannot be sent directly to the market but to a processing plant were they are boiled or sterilised. Bivalves can be collected from Class B areas but need purification prior to be placed live on the market. Class C areas are those from which bivalves can be collected but placed on the market live only after relying over a long period so as to meet Class A requirements. When requirements for commercialization are not met, the competent authority must close the production area, with the consequent economic losses.

Figure 7 shows the evolution of the percentage of bivalve harvesting sites classified as A, B or C Class (see above) in two areas of the Ría; Redondela, with a stable acceptable status, alternating $\mathrm{B}$ and $\mathrm{A}$ classification, and Moaña, affected by direct urban discharges until the installation of a WTP in 2002.

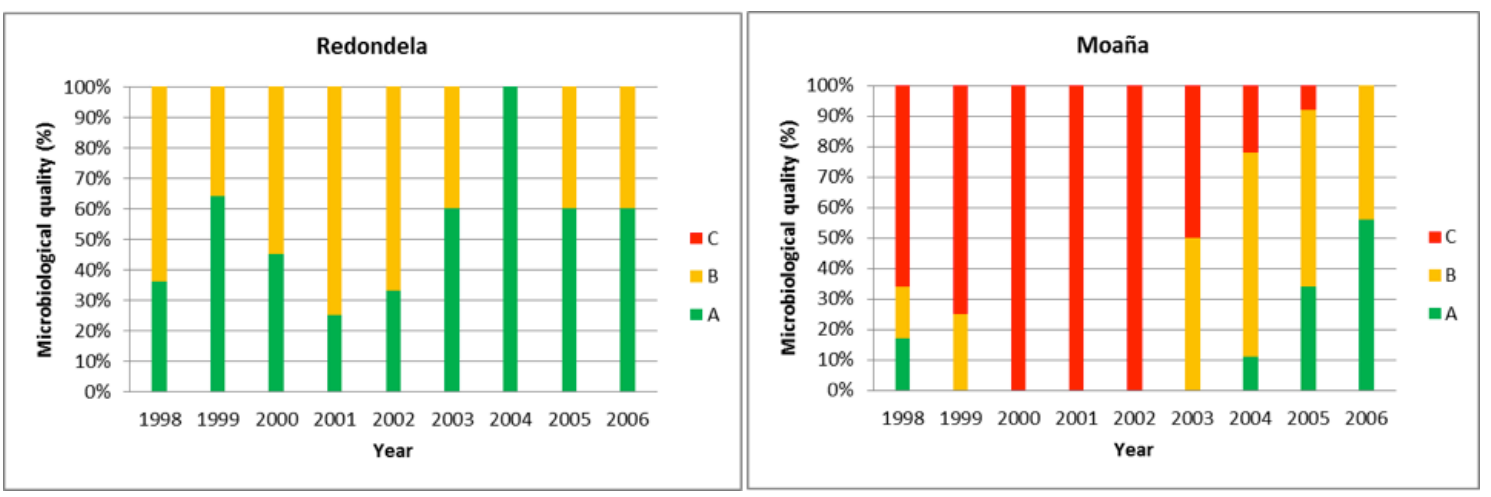

Figure 7.- Temporal evolution in the percentage of bivalve harvesting areas classified from A (best) to $\mathrm{C}$ (worst) according to the microbiological quality of shellfish in two areas of Ría de Vigo (NW Iberian Peninsula). The improvement in Moaña can be associated to municipal sewage treatment facilities opened in 2002. (Data from Álvarez 2008) 
Microbial pollution originated from incomplete depuration of the urban sewage is probably the main threat for shellfish production in the Ría de Vigo. In 2000, only 20\% of the 12 million population equivalent from the North coast of Spain was provided with wastewater treatment services (Díez et al. 2000). In December 2005 the Court of Justice of the European Union declared that the Kingdom of Spain has not met the duties derived from Directive 79/923/EEC relative to the water quality requirements for shellfish culture due to lack of measures for the abatement of microbial pollution in the Ría de Vigo. This pervasive and diffuse kind of pollution is originated not only from large WTP but also from small population nuclei in otherwise relatively pristine areas (Beiras 2008). However, according to official sources, in 2007 the city of Vigo WTP, that lacks tertiary treatment, was responsible for a large fraction of the microbial contamination of the Ría. This situation is expected to reverse in the near future due to the current construction of a new, properly dimensioned, treatment plant.

\section{Conclusion}

This review illustrates the role of Ría de Vigo as a model system where environmental pressures on the coastal ecosystem coexist with an important fish extraction and shellfish production activity and with almost pristine marine natural areas over a reduced spatial scale.

The progressive accumulation of human population in the Ría de Vigo led to a significant increase of its impact on the marine environment. Loss of breeding and nursery habitats of commercial species due to landfilling and deterioration of water quality, particularly resulting from the supply of nutrients, organic matter and enteric bacteria through small rivers and sewage plants located along the shoreline, has been also described and quantified (see Figure 5). In spite of the considerable magnitude of chemicals and enteric bacteria entering into this environment, water quality conditions are largely compatible with the provision of production services by the marine ecosystem due to the hydrodynamics of the Ría, characterized by extended periods of short water renewal times associated to the wind-driven upwelling process. Unlike typical shallow estuaries, where ecological dynamics is mainly controlled by the landsea interaction, in the case of the Ría de Vigo, the effect of large scale atmospheric and oceanic processes, such as upwelling, is also relevant, being therefore vulnerable to environmental processes occurring at the global scale.

Nevertheless, pollution of the Ría de Vigo remains significant and generates an intense social response from shellfish producers, environmental organizations and the citizenship in general, asking the administrations for a stronger commitment leading to 
the effective and rapid decline of pollution levels in the Ría de Vigo. We conducted an analysis of the different conflicts reported by local newspapers throughout the past 20 years, showing that pollution-related conflicts accounted for $20 \%$ of the total number of conflicts published, followed by those associated with fish and shellfish exploitation activities (16\%), urbanization of the coastline (16\%), coastal landfills (13\%) and regression of natural protected areas $(12 \%)$.

Conflict management and, ultimately, the introduction of sustainability principles in a given territory and society is always a rather complex process because they will demand short-term restrictions to individuals in order to achieve long-term societal gains. This is probably the major difficulty for the sustainable management of extensive aquaculture and shellfisheries in an area under human pressure such as the Ría de Vigo. Nevertheless, environmental economy warns us that economic systems are just one component of a broader system that includes not only human activities but also the processes that support life on the biosphere. To sustain economic development with a minimum impact on ecosystem services such as air and water self-depuration, nutrient cycling and renewal of natural resources is one of the fundamental challenges for human societies living in the early stages of the anthropocene.

The particular hydrodynamics of the Ría de Vigo and the different time and spatial scales associated with the processes controlling its ecology described in this review, together with the diversity of marine uses taking place in less than $160 \mathrm{~km}^{2}$, which includes shellfish production (see Fig. 4), confer this coastal ecosystem unique conditions as a natural laboratory where the interaction between human activity and marine ecological processes can be studied within the framework of the World Harbour Project. 


\section{Appendix}

Table 1. Demographic evolution (number of inhabitants) of the municipalities surrounding the Ría de Vigo and the total for the county (Provincia de Pontevedra).

\begin{tabular}{|c|c|c|c|c|c|c|c|c|c|c|c|c|c|}
\hline Municipios / Año & 1900 & 1910 & 1920 & 1930 & 1940 & 1950 & 1960 & 1970 & 1981 & 1991 & 2001 & 2011 & 2014 \\
\hline Cangas & 8011 & 10471 & 12718 & 14418 & 15836 & 15334 & 17115 & 19026 & 20798 & 21729 & 23981 & 26332 & 26567 \\
\hline Moaña & 6091 & 7812 & 8020 & 9634 & 11305 & 11106 & 12736 & 15060 & 17053 & 16781 & 17887 & 19277 & 19365 \\
\hline Vilaboa & 4179 & 4545 & 4546 & 4824 & 4912 & 4839 & 5061 & 5394 & 6001 & 5785 & 5735 & 6033 & 5972 \\
\hline Soutomaior & 3275 & 3405 & 3524 & 3630 & 4000 & 4232 & 4288 & 5775 & 5434 & 4907 & 5405 & 7274 & 7356 \\
\hline Redondela & 10843 & 11985 & 13644 & 14996 & 16927 & 17024 & 17206 & 22128 & 27202 & 27751 & 29003 & 29947 & 29909 \\
\hline Vigo & 45913 & 60678 & 78282 & 96696 & 89118 & 137873 & 144914 & 197144 & 258724 & 278050 & 280186 & 295623 & 294997 \\
\hline Nigrán & 6180 & 6493 & 6918 & 6974 & 7768 & 7968 & 8085 & 9048 & 12336 & 14008 & 16110 & 17870 & 17715 \\
\hline Gondomar & 7842 & 8281 & 8219 & 8219 & 8570 & 9037 & 8133 & 8679 & 10009 & 10440 & 12176 & 14086 & 14051 \\
\hline Baiona & 4423 & 4828 & 5318 & 5596 & 6075 & 6420 & 6585 & 7887 & 9702 & 9690 & 10931 & 11940 & 12233 \\
\hline Ría de Vigo & 96757 & 118498 & 141189 & 164987 & 164511 & 213833 & 224123 & 290141 & 367259 & 389141 & 401414 & 428382 & 428165 \\
\hline Provincia de Ponteve & 457262 & 495356 & 533419 & 568011 & 641763 & 671609 & 680229 & 750701 & 859897 & 886949 & 903759 & 954877 & 950919 \\
\hline
\end{tabular}




\section{References}

Alonso-Pérez, F., Castro, C.G., 2014 Benthic oxygen and nutrient fluxes in a coastal upwelling system (Ria de Vigo, NW Iberian Peninsula): seasonal trends and regulating factors. Mar. Ecol. Prog. Ser. 511, 17-32.

Alonso-Pérez, F., Ysebaert, T., Castro, C.G., 2010. Effects of suspended mussel culture on benthic-pelagic coupling in a coastal upwelling system (Ría de Vigo, NW Iberian Peninsula). J. Exp. Mar. Biol. Ecol. 382, 96-107.

Alonso-Pérez, F., Zúñiga, D., Arbones, B., Figueiras, F.G., Castro, C.G., 2015. Benthic fluxes, net ecosystem metabolism and seafood harvest: Completing the organic carbon balance in the Ría de Vigo (NW Spain). Estuar. Coast. Shelf. Sci. 163, 54-63.

Álvarez, C. 2008. Microbiología. In: González-Garcés, A., Vilas, F., Álvarez Salgado, X.A. (Eds.) La Ría de Vigo. Una aproximación integral al ecosistema marino. pp. 243-245. Instituto de Estudios Vigueses.

Álvarez-Iglesias, P., Quintana, B., Rubio, B., Pérez-Arlucea, M., 2007. Sedimentation rates and trace metal input history in intertidal sediments from San Simón Bay (Ría de Vigo, NW Spain) derived from ${ }^{210} \mathrm{~Pb}$ and ${ }^{137} \mathrm{Cs}$ chronology. J. Environ. Radiact. 98: 229-250.

Alvarez-Salgado, X.A., Gago, J., Míguez, B.M., Gilcoto, M., Pérez, F.F., 2000. Surface waters of the NW Iberian margin: upwelling on the shelf versus outwelling of upwelled waters from the Rías Baixas. Estuar. Coast. Shelf Sci. 51, 821-837.

Alvarez-Salgado, X.A., Beloso, S., Joint, I., Nogueira, E., Chou, L., Pérez, F.F., Groom, S., Cabanas, J.M., Rees, A.P., Elskens, M., 2002. New production of the NW Iberian shelf during the upwelling season over the period 1982-1999. Deep-Sea Res Part I 49, $1725-1739$

Alvarez-Salgado, X.A., Labarta, U, Fernández-Reiriz, M.J., Figueiras, F.G., Rosón, G., Piedracoba, S., Filgueira, R., Cabanas, J.M., 2008. Renewal time and the impact of harmful algal blooms on the extensive mussel raft culture of the Iberian coastal upwelling system (SW Europe). Harmful Algae 7, 849-855.

Alvarez-Salgado, X.A., Borges, A.V., Figueiras, F.G., Chou, L., 2010. Iberian margin: the Rías. In: Liu, K.K., Atkinson, L., Quiñones, R., Talaue-McManus, L. (Eds) Carbon and Nutrient Fluxes in Continental Margins: A Global Synthesis, IGBP Book Series, Springer, Berlin, chapter 2.6, pp. 103-120.

Arístegui, J., Barton, E.D., Álvarez-Salgado, X.A., Santos, A.M.P., Figueiras, F.G., Kifani, S., Hernández-León, S., Mason, E., Machu, E., Demarcq, H. 2009. Sub-regional ecosystem variability in the Canary Current upwelling. Prog. Oceanogr. 83, 33-48. 
Autoridad Portuaria de Vigo (2015). Memoria anual 2014. Annual report 2014. Vigo. Puertos del Estado, Ministerio de Fomento.

Barton, E., 1998. Eastern boundary of the North Atlantic: Northwest Africa and Iberia. Coastal segment (18, E). In: Robinson, A., Brink, K.H. (Eds.), The Sea, vol. 11. John Wiley \& Sons Inc., pp. 633-657.

Barton, E.D., Largier, J.L., Torres, R., Sheridan, M., Trasviña, A., Souza, A., Pazos, Y., Valle-Levinson, A., 2015. Coastal upwelling and downwelling forcing of circulation in a semi-enclosed bay: Ria de Vigo. Prog. Oceanogr. 134, 173-189.

Beiras, R., Fernández, N., Bellas, J., Besada, V., and González-Quijano, A., Nunes, T., 2003. Integrative assessment of marine pollution in Galician estuaries using sediment chemistry, mussel bioaccumulation, and embryo-larval toxicity bioassays. Chemosphere $52,1209-1224$.

Beiras, R. 2008. Calidade da auga para o marisqueo nas rías galegas. In: M. Rey Méndez, Fernández Casal, J., Lodeiros Seijo, C., Guerra Díaz, A. (Eds.). X Foro dos recursos mariños e da acuicultura das rías galegas e I Foro Iberoamericano dos recursos mariños e da acuicultura. pp 693-699.

Bruschi, V.M., Bonachea, J., Remondo, J., Gómez-Arozamena, J., Rivas, V., Méndez, G., Naredo, J.M., Cendrero, A., 2013. Analysis of geomorphic systems' response to natural and human drivers in northern Spain: Implications for global geomorphic change. Geomorphology, 196, 267-279.

Campillo Ruiz, A., Méndez Martínez, G., Souto González, X.M. 1993. A poboación e a acción xeodemográfica. Xeografía de Galicia, Tomo 4. Gran Enciclopedia Galega Edicións. Santiago de Compostela. 278 pp.

Carro, N., García, I., Ignacio, M., Mouteira, A, 2010. Spatial and temporal trends of PCBs (polychlorinated biphenyls) in mussel from Galician coast (1998-2008). Environ. International 36, 873-879.

Centre for industrial studies, 2012. Integrated environmental regeneration of Ria de Vigo.

Díez et al. 2010 Chapter 9. The North Coast of Spain. In: Sheppard, C. (Ed) Seas at the Millenium: An Environmental Evaluation.

Durán, I., Nieto, O. 2011. Electrochemical speciation of dissolved $\mathrm{Cu}, \mathrm{Pb}$ and $\mathrm{Zn}$ in an estuarine ecosystem (Ria de Vigo, NW Spain): Comparison between data treatment methods. Talanta 85, 1888-1896. 
Evans, G., Prego, R., Marshall, J.E. 2011. Organic matter in ría sediments: relevance of terrestrial sources and temporal variations in rates of accumulation. Est. Coast. Shelf Sci. 94. 246-254.

Figueiras, F.G., Jones, K.J., Mosquera, A.M., Alvarez-Salgado, X.A., Edwards, A., MacDougall, N., 1994. Red tide assemblage formation in an estuarine upwelling ecosystem: Ria de Vigo. J. Plank. Res. 16 (7), 857-878.

Figueiras, F.G., Labarta, U., Fernández Reiriz, M.J., 2002. Coastal upwelling, primary production and mussel growth in the Rías Baixas of Galicia. Hydrobiologia 484, 121-131.

Fraga, S., Anderson, D.M., Bravo, I., Reguera, B., Steidinger, K.A., Yentsch, C.M., 1988. Influence of upwelling relaxation on dinoflagellates and shellfish toxicity in Ría de Vigo, Spain. Estuar. Coast. Shelf Sci. 27, 349-361.

Gago, J., Alvarez-Salgado, X.A., Nieto-Cid, M., Brea, S., Piedracoba, S., 2005. Continental inputs of C, N, P and Si species to the Ría de Vigo (NW Spain). Estuar. Coast. Shelf Sci. 65, 74-82

Gómez-Gesteira, M., Beiras, R., Presa, P., Vilas, F. 2011a. Coastal Processes in NorthWest Iberia. Cont. Shelf Res. 31. 367-375.

Gomez-Gesteira, M., Gimeno, L., deCastro, M., Lorenzo, M.N., Alvarez, I., Nieto, R., Taboada, J.J., Crespo, A.J.C., Ramos, A.M., Iglesias, I., Gómez-Gesteira, J.L., Santo, F.E., Barriopedro, D., Trigo, I.F., 2011b. The state of climate in NW Iberia. Clim. Res. 48, 109-144.

Gonzalez-Vilas, L., Spyrakos, E., Torres-Palenzuela, J.M., Pazos, Y., 2014. Support Vector Machine-based method for predicting Pseudo-nitzschia spp. blooms in coastal waters (Galician rias, NW Spain). Prog. Oceanogr. 124, 66-77.

Howarth, R.J., Evans, G., Croudace, I.W., Cundy, A.B. 2005. Sources and timing of anthropogenic pollution in the Ensenada de San Simón (Inner Ría de Vigo), Galicia, NW Spain: an application of mixture-modelling and non-linear optimization to recent sedimentation. Sci. Total Environ. 340. 149-176.

Méndez, G. and Vilas, F., 2005. Geological antecedents of the Rias Baixas (Galicia, northwest Iberian Peninsula). J. Mar. Syst. 54: 195-207.

Moschino. V., Del Negro, P., De Vittor, C. and Da Ros. L. (2016). Biomonitoring of a polluted coastal area (Bay of Muggia, Northern Adriatic Sea): A five-year study using transplanted mussels. Ecotoxicology and Environmental Safety, 128, 1-10. DOI: 10.1016/j.ecoenv.2016.02.006 
Nogueira, E., Perez, F.F., Rios, A.F., 1997. Seasonal patterns and long-term trends in an estuarine upwelling ecosystem (Ria de Vigo, NW Spain). Estuar. Coast. Shelf Sci. 44, 285-300.

Pellerin, J., and Amiard, J. (2009). Comparison of bioaccumulation of metals and induction of metallothioneins in two marine bivalves (Mytilus edulis and Mya arenaria). Comparative Biochemistry and Physiology - C Toxicology and Pharmacology, 150(2), 186-195. DOI: 10.1016/j.cbpc.2009.04.008

Pérez, F.F., Padín, X.A., Pazos, Y., Gilcoto, M., Cabanas, J.M., Pardo, P.C., Doval, M.D., Fariña-Busto, L., 2010. Plankton response to weakening of the Iberian coastal upwelling. Glob. Change Biol. 16, 1258-1267.

Pérez-Arlucea, M., Mendez, G., Clemente, F., Nombela, M., Rubio, B., Filgueira, M., 2005. Hydrology, sediment yield, erosion and sedimentation rates in the estuarine environment of the Ria de Vigo, Galicia, Spain. J. Mar. Sys. 54. 209-226.

Prego, R. \& Cobelo-García, A., 2003. Twentieth century overview of heavy metals in the Galician Rias (NW Iberian Peninsula). Environmental Pollution, 121 (3): 425-452.

Richards, G.P. 2003. The evolution of molluscan shellfish safety. In: Villalba, A., Reguera, B., Romalde, J.L., Beiras, R. (Eds.) Molluscan Shellfish Safety. Xunta de Galicia-Intergovernmental Oceanographic Commission of UNESCO. pp. 221-245.

Reguera, B., Bravo, I., Fraga, S., 1995. Autoecology and some life history stages of Dinophysis acuta Ehrenberg. J. Plankton Res. 17, 999-1015.

Richthofen, F. von, 1886. Führer für Forschungsreisende. Oppenheim. Berlin.

Sánchez-Marín, P., Beiras, R. 2008. Lead concentrations and size dependence of lead accumulation in the clam Dosinia exoleta from shellfish extraction areas in the Galician Rías (NW Spain)Aquat. Living Resour. 21, 57-61.

Søndergaard, J., Asmund, G., Johansen, P. and Rigét, F. (2011). Long-term response of an arctic fiord system to lead-zinc mining and submarine disposal of mine waste (Maarmorilik, West Greenland). Marine Environmental Research, 71, 5, 331-341. DOI: 10.1016/j.marenvres.2011.03.001

Suris-Regueiro, J.C., Garza-Gil, D., Varela-Lafuente, M. 2014. Socio-economic quantification of fishing in an European urban area: the case of Vigo. Marine Policy. 43: 347-358.

Viana, I., Bode, A., 2013. Stable nitrogen isotopes in coastal macroalgae: Geographic and anthropogenic variability. Sci. Total Environ. 443. 887-895. 
Vilas, F., Bernabeu, A. and Méndez, G., 2005. Sediment distribution pattern in the Rias Baixas (NW Spain): main facies and hydrodynamic implications. J. Mar. Sys. 54. 261-276.

von Richthofen, F., 1886. Führer für Forschungsreisende. Berlin. Oppenheim (Rías: pp. 308-310)

Zhang, W., Liu, X., Cheng, H., Zeng, E. Y., and Hu, Y. (2012). Heavy metal pollution in sediments of a typical mariculture zone in South China. Marine Pollution Bulletin, 64(4), 712-720. DOI: 10.1016/j.marpolbul.2012.01.042 